\title{
Preservative effects of aqueous and ether extracts of Aframomum melegueta on West African soft cheese
}

\author{
Badmos AA ${ }^{1}$, A Ahmad-el Imam ${ }^{2}$, AA Annongu ${ }^{1}$, AT Yusuff ${ }^{1}$, RMO Kayode ${ }^{3}$, KO Salami $^{3}$, IA \\ Ahutu $^{1}$ and AO Lawal ${ }^{4}$
}

${ }^{1}$ Department of Animal Production, University of Ilorin, Ilorin; ${ }^{2}$ Department of Microbiology, University of Ilorin, Ilorin; ${ }^{3}$ Department of Home Economics and Food Science. University of Ilorin, Ilorin, ${ }^{4}$ ITAD Ltd, Hove, UK

\begin{abstract}
The Total Bacterial Count, proximate composition, and sensory evaluation of West African Soft Cheese supplemented with aqueous and ether extracts of the spice Aframomum melegueta (at 0\%, 1\%, 2\% and $3 \%$ each) were determined with a completely randomized design. Effects of the spice were monitored for 3 days. The results revealed that $3 \%$ concentration of the ether extract of the spice was the most inhibitory $(p<0.05)$ of microbial growth for the duration of the experiment and it also significantly improved the fat, ash and protein contents of the cheese. The study recommended the addition of $3 \%$ ether extract of $A$. melegueta as an additive to fortify West African soft cheese.
\end{abstract}

Key words: cheese quality, microbial load, sensory evaluation, spice

Bangladesh Animal Husbandry Association. All rights reserved. $\quad$ Bang. J. Anim. Sci. 2017. 46 (1): 51-56

\section{Introduction}

Cheese is one of the most important products of milk, known worldwide for its palatability, high nutritional content and versatility. It is highly desirable and can be taken as food or snack by people of all ages. Its high nutritional content is also an added advantage as it is a very rich source of protein, vitamins, and minerals which are essential for developing children and convalescing adults. Its ability to be used in almost any dish and also as a substitute for meat and fish adds to its popularity. Cheese is made in almost every country of the world with the existence of more than 2,000 varieties (O'Connor, 1993). It is today a major business worth billions of dollars in many industrialized countries. Indeed, cheese varieties are now unique products in their own right and cheesemaking has advanced beyond being merely a food preservation technique (Aworh, 2008). West African soft cheese (wara) is a soft, white, unripened cheese that originated from Fulani cattle rearers in the Northern part of the West Africa, including Nigeria, and is an excellent source of protein, fats, vitamins and minerals such as calcium, iron and phosphorus (Ogundiwin, 1978; Oladipo and Jadesinmi 2013; Badmos and Joseph, 2012).
A major problem associated with the production of West African Soft Cheese 'wara' is it's short shelf life of 2-3 days when immersed in whey (Belewu et al. 2005). A lot of research has gone into the improvement of its shelf life by using different preservatives. (Aworh \& Egounlety, 1985; Anon, 1995). The use of $0.8 \%$ propionic acid and $0.8 \%$ sodium benzoate in the preservation of cheese for 8 days have been reported by Joseph and Akinyosoye (1997). Preservatives used in the food industry are however coming under increasing scrutiny and reappraisal. Synthetic antioxidants are effective oil stabilisers but concern about their possible adverse effects on consumption is increasing. Thus there is the need to consider the potency of natural spices and ingredients, as reported by Ashaye et al. (2006) and Belewu et al. (2005). This study aims at addressing the preservative capacity of alligator pepper (Aframomum melegueta) which has been found to have strong antimicrobial properties, and capable of improving nutritional components of soft cheese in storage. The seeds have pungent peppery taste due to aromatic ketones (Galal, 1996). According to Oladunmoye \& Dada (2007), Aframomum melegueta was tested for antimicrobial effects on five pathogenic bacteria which include Bacillus cereus, Staphylococcus

*Corresponding author: badmos111@yahoo.com 


\section{Aframomum melegueta on soft cheese}

aureus, Escherichia coli, Salmonella typhi and klebsiella pneumonia. Ashaye et al (2006) studied some cheese preservative properties of a related Aframomum species (A. danielli).

The objectives of the study include the determination of preservative potency of aqueous and ether extracts of $A$. melegueta, the effect of the preservative on nutrient value of West African Soft Cheese, and the optimal level on inhibition of spoilage micro-organisms.

\section{Materials and Methods}

\section{Preparation of aqueous extract of Aframomum melegueta}

The powder of the seeds was extracted as follows: The powdered seeds $(250 \mathrm{~g})$ were put in a round bottom flask. One litre of sterile distilled water was added into each flask, covered with aluminum foil and allowed to stand for about five days. The mixture was thoroughly shaken and filtered. The filtrate was then concentrated by heating over a water bath for evaporation of significant amount of moisture. The crude extract was then obtained in a beaker, and kept in the refrigerator at $4^{\circ} \mathrm{C}$ (Bankole and Somorin, 2010).

\section{Preparation of ether extract of A. melegueta}

The seeds were winnowed and milled into powder using mortar and pestle, $50 \mathrm{~g}$ of the powdered seeds was percolated with $250 \mathrm{ml}$ of petroleum ether at room temperature $\left(27^{\circ} \mathrm{C}\right)$ for 24 hours and filtered. The extract obtained was concentrated at $50^{\circ} \mathrm{C}$ (Afolabi et al, 2011).

\section{Preparation of West African soft cheese}

Some quantities of sodom apple stem (Calotropis procera) were collected, rinsed air dried and crushed with a sterilized enamel mortar and pestle. Ten grams $(10 \mathrm{~g})$ of the mash was weighed and sieved with $20 \mathrm{ml}$ of distilled water (Badmos \& Joseph, 2012), and labeled as sodom apple extract. Milk of $100 \mathrm{ml}$ was poured into each of seventy (70) heating vessels ( 7 treatments in 10 replicates), which were immersed in a heated water bath. The milk in the vessels were heated to approximately $50^{\circ} \mathrm{C}$ for about 30 - 40 minutes, after which $3 \mathrm{ml}$ of the fortified sodom apple extract (fortified with $A$. melegueta extract as described in the treatment plan below) were added to the warm milk in each vessel. Heating continued until coagulation started about 5 minutes later. It was boiled for a further 20 minutes to enable whey expulsion and inactivate the plant enzymes. The curd was then removed and put in a raffia basket to enable drainage of whey and give it shape and size.

\section{The treatment plan}

Seven (7) varying levels of $A$. melegueta (alligator pepper) fortifications/ inoculation represent 7 treatments, viz: Treatment 1 , no extract added (Control); Treatment 2, 1 percent aqueous $A$. melegueta extract; Treatment 3, 2 percent aqueous $A$. melegueta extract; Treatment 4, 3 percent aqueous $A$. melegueta extract; Treatment 5,1 percent ether $A$. melegueta extract; Treatment 6, 2 percent ether A. melegueta extract and Treatment 7, 3 percent ether $A$. melegueta extract.

\section{Parameters evaluated}

These include proximate composition- crude protein, moisture content, ether extract, and ash (AOAC,1995); and Total Bacterial Count (TBC); sensory evaluation (flavour, texture, taste and overall acceptability), which was done after 48 hours of incubation at $37{ }^{\circ} \mathrm{C}$ by counting individual colony in the petri dish (Fawole \& Osho, 2007). Sensory analysis (flavour, texture, taste and overall acceptability) of the cheese samples was also made by a panel of judges. A thirty member trained panelists familiar with the taste of Cheese examined the samples independently (Lammond, 1970; Ashaye et al, 2006). Evaluation was based on colour, taste, texture, aroma, and the overall acceptability. Score was based on hedonic scale of 1-9 ( 1 = like extremely and $9=$ dislike extremely).

\section{Statistical analysis}

The data collected from the above were subjected to the analysis of variance (ANOVA) by the Completely Randomized Design. The difference between the means was separated using Duncan Multiple Range Test (Steel \& Torrie, 1980). In total 10 replications were performed.

\section{Results}

Table 1 shows that soft Cheese fat content increased $(p<0.05)$ with increasing level of 
Badmos et al. (2017) Bang. J. Anim. Sci. 46 (1):51-56

extract. The highest cheese fat was obtained by the $3 \%$ ether extract, while the control cheese had the lowest fat content. The cheese protein content increased steadily $(p>0.05)$ with increasing levels of the extract of $A$. melegueta. The trend was not consistent for the aqueous extract of the spice. The highest cheese protein was obtained by the $3 \%$ ether extract, while the $1 \%$ aqueous extract cheese was lowest in protein. The cheese ash content was higher $(p<0.05)$ with increasing levels of the extracts, and the $3 \%$ ether extract gave the highest cheese ash. The cheese moisture content was similar in all the treatments, but was significantly lowest for the $3 \%$ ether extract. Cheeses made from higher levels of extract were consistently lower $(p<0.05)$ in TBC for the three days of microbiological examination (Table 2 ). The counts increased from day 1 to day 2, and onwards to day 3 . The rise was however smaller with higher levels of the extract. The $3 \%$ ether extract appeared to be most inhibitory on bacteria growth, and actually decreased the bacteria population in day 3 .

The sensory study (Table 3 ) showed that the control cheese was the most preferred $(p<0.05)$ by the panelists while the cheese containing ether extract of the spice was not so preferred by the panelists. The ratings followed this same trend for cheese colour, taste, aroma, texture, and general acceptability.

Table 1. Proximate analysis of West African soft cheese treated with aqueous and ether extracts of $A$. melegueta

\begin{tabular}{|c|c|c|c|c|c|c|c|c|c|}
\hline Parameters & Control & Eth1\% & Eth2\% & Eth3\% & Aq1\% & Aq2\% & Aq3\% & \pm SEM & $F_{6,17}$ \\
\hline Fat & $19.09^{c}$ & $20.40^{b}$ & $20.89^{b}$ & $26.84^{\mathrm{a}}$ & $20.29^{b}$ & $20.56^{b}$ & $20.89^{b}$ & 0.06 & 522.74 \\
\hline Protein & 12.47 & 12.40 & 12.46 & 12.55 & 11.99 & 12.10 & 12.00 & 0.01 & 23.102 \\
\hline Ash & $1.57^{\mathrm{a}}$ & $1.62^{\mathrm{a}}$ & $1.82^{\mathrm{b}}$ & $2.07^{c}$ & $1.60^{\mathrm{a}}$ & $1.61^{\mathrm{a}}$ & $1.74^{b}$ & 0.07 & $50.15 E^{*}$ \\
\hline Moisture & $56.87^{b}$ & $55.56^{\mathrm{b}}$ & $55.36^{\mathrm{b}}$ & $49.11^{\mathrm{a}}$ & $53.47^{\mathrm{ab}}$ & $55.79^{b}$ & $55.35^{\mathrm{b}}$ & 0.00 & $173.78^{*}$ \\
\hline
\end{tabular}

${ }^{A b c}$ : means followed by different superscripts in the same row differ significantly. Eth/ Aq means percentage of ether and aqueous extracts

Table 2. Bacterial load of West African soft cheese treated with aqueous and ether extracts of $A$. melegueta $\left(10^{6} \mathrm{cfu} / \mathrm{ml}\right)$

\begin{tabular}{rrrrrrrrrr}
\hline Day & Control & Eth1\% & Eth2\% & Eth3\% & Aq1\% & Aq2\% & Aq3\% & 土SEM & F \\
\hline 0 & $1.25^{\mathrm{b}}$ & $1.16^{\mathrm{ab}}$ & $1.12^{\mathrm{a}}$ & $1.13^{\mathrm{a}}$ & $3.80^{\mathrm{d}}$ & $3.40^{\mathrm{c}}$ & $1.14^{\mathrm{a}}$ & 0.01 & $14.73 \mathrm{E} 2$ \\
1 & $7.43^{\mathrm{e}}$ & $1.44^{\mathrm{c}}$ & $1.45^{\mathrm{c}}$ & $1.23^{\mathrm{a}}$ & $6.53^{\mathrm{d}}$ & $1.24^{\mathrm{a}}$ & $1.38^{\mathrm{b}}$ & 0.00 & $36.96 \mathrm{E} 4$ \\
2 & $7.43^{\mathrm{g}}$ & $2.23^{\mathrm{d}}$ & $2.15^{\mathrm{c}}$ & $1.10^{\mathrm{a}}$ & $1.24^{\mathrm{b}}$ & $2.41^{\mathrm{e}}$ & $2.99^{\mathrm{f}}$ & 0.00 & $88.61 \mathrm{E} 2$ \\
\hline
\end{tabular}

${ }^{A b C}$ : means followed by different superscripts in the same row differ significantly. Eth/ Aq means percentage of ether and aqueous extracts

Table 3. Effect of aqueous and ether extracts of $A$. Melegueta on the sensory quality of West African soft cheese

\begin{tabular}{llllllllll}
\hline Parameters & Control & Eth1\% & Eth2\% & Eth3\% & Aq1\% & Aq2\% & Aq3\% & 土SEM & F \\
\hline Colour & $3.31^{\mathrm{d}}$ & $2.03^{\mathrm{ab}}$ & $2.65^{\mathrm{c}}$ & $1.81^{\mathrm{a}}$ & $2.70^{\mathrm{c}}$ & $2.43^{\mathrm{bc}}$ & $2.53^{\mathrm{c}}$ & 0.04 & $60.34 \mathrm{E} 4$ \\
Taste & $4.36^{\mathrm{e}}$ & $2.69^{\mathrm{b}}$ & $3.17^{\mathrm{d}}$ & $2.24^{\mathrm{a}}$ & $3.00^{\mathrm{c}}$ & $2.93^{\mathrm{c}}$ & $3.13^{\mathrm{d}}$ & 0.00 & 217.55 \\
Aroma & $3.86^{\mathrm{c}}$ & $2.46^{\mathrm{ab}}$ & $2.93^{\mathrm{b}}$ & $2.24^{\mathrm{a}}$ & $2.44^{\mathrm{ab}}$ & $2.59^{\mathrm{ab}}$ & $2.82^{\mathrm{ab}}$ & 0.08 & 2.22 \\
Texture & $3.76^{\mathrm{f}}$ & $2.36^{\mathrm{b}}$ & $2.79^{\mathrm{d}}$ & $2.07^{\mathrm{a}}$ & $2.81^{\mathrm{d}}$ & $2.65^{\mathrm{c}}$ & $3.03^{\mathrm{e}}$ & 0.01 & 421.09 \\
Acceptability & $4.14^{\mathrm{f}}$ & $2.59^{\mathrm{b}}$ & $3.39^{\mathrm{e}}$ & $2.17^{\mathrm{a}}$ & $2.96^{\mathrm{c}}$ & $3.21^{\mathrm{d}}$ & $3.21^{\mathrm{d}}$ & 0.07 & \\
\hline
\end{tabular}

${ }^{A B C}$ : means followed by different superscripts in the same row differ significantly. Eth/ Aq means percentage of ether and aqueous extracts 


\section{Aframomum melegueta on soft cheese}

\section{Discussion}

The ash content of the cheese was higher with increasing level of extracts, and particularly so for the ether extract treatments. This may be due to the minerals present in the spice and those produced by microbial activities (Adegoke and Gopalakrishna, 1998; Ashaye et al., 2006). Odebunmi et al. reported that A. melegueta has considerably high quantities of calcium (388 $\mathrm{mg} / \mathrm{Kg}$ dry matter), magnesium (960 mg/Kg), iron $(37.8 \mathrm{mg} / \mathrm{Kg})$, zinc $(32.93 \mathrm{mg} / \mathrm{Kg})$ and manganese $(68.53 \mathrm{mg} / \mathrm{Kg})$. The extract of the spice is thus expected to be rich in minerals.

The increase of cheese fat content with increasing level of ether extract inclusion could be due to the fact that the ether was able to extract most of the fat in the spice (Dari, 2009) and at an inclusion level of $3 \%$, the fat content extracted was higher when compared to the other inclusion levels. Odebunmi et al.(2009) reported a crude fat content of $2.55 \%$ for $A$. melegueta There was no significant difference in the protein content between the treatments, but the $3 \%$ ether extract cheese had the numerically highest protein content. It appeared that many factors affected the cheese protein content, and the interaction of such factors did not allow for a simple trend. The relationship between cheese protein and fat has been earlier established. Chen et. al. (1996) reported that casein forms the structural matrix that traps moisture and fat. The presence of some microorganisms and/or their enzymes in the control (which had the highest microbial count) is another factor. These microbes aid in the synthesis of nitrogenous substance (Ashaye et al., 2006), thereby increasing the protein content. The moisture content of the cheese were statistically similar, except for the $3 \%$ ether extract cheese which was the lowest. This might be due to the high fat content as reported above. Higher content of extract might have enhanced higher activities of micro organisms and enzymes produced by them, as was reported by Ashaye et al., 2006). This differences in volume would definitely have allowed for higher fat content with increasing level of extract.

The cheese with ether extract (Table 2), particularly at higher levels, had higher inhibition of bacteria growth, on the other hand, the aqueous extract of the spice had the least effect on the bacteria isolates and microbial load of the cheese produced. The control was observed to have the highest microbial load among all the treatments. The difference in the antibacterial properties of the plant extracts might be attributable to age of the plant, extracting solvent, method of extraction and time of harvesting of plant materials (Amadioha et al, 1999). The result of this work showed that the seed extract of $A$. melegueta inhibited the growth of bacteria. The antibacterial effect of $A$. melegueta is apparently due to the phytochemical constituents present in the extract. $A$. melegueta seeds have been reported to be a rich source of phytonutrients such as flavonoids, phenolic compound tannins, saponin, terpernoids, cardiac glycosides and alkaloids (Doherty et al, 2010; Chiejina \& Ukeh, 2012).

The biological function of flavonoids includes protection against allergies, inflammation, free radicals, platelet aggregation, microbes, ulcers, hepatoxins, viruses and tumors (Okwu, 2004). This may be the reason for the use of the extracts of this plant in the treatment of intestinal troubles in herbal medicine (Okwu, 2004). The presence of phenolic compounds in the seed of $A$. melegueta is also an indication of the plant being an antibacterial agent. This is because phenols and phenolic compounds have been extensively used in disinfection and remains the standard with which other bactericides are compared. Phenolic compounds as electron donors are readily oxidized to form phenolate ions or quinine, an electron acceptor (Doherty et al, 2010). Extracts from $A$. melegueta therefore have potent antiseptic or bactericidal properties (Okwu, 2004). Ilondu et al. (2001) reported that some plants contain phenolic substances and essential oils, which are inhibitory to microorganisms. The presence of these compounds in these extracts has also been reported to be responsible for their antifungal properties (Ahmed \& Stoll, 1996).

The sensory study showed that the control cheese was the most preferred by the panelists while the cheese from the ether extract of the spice was the least preferred by the panelists. This may be attributed to the fact the panelists 


\section{Badmos et al. (2017) Bang. J. Anim. Sci. 46 (1):51-56}

were more familiar with the sensory qualities of the cheese produced without the extract and it could also be attributed to the quantity of saponin content in the extracts. Some of the general characteristics of saponin include: formation of foam in aqueous solutions, hemolytic activity, cholesterol binding properties and bitterness (Okwu, 2004). The high tannin content could be partly responsible for the hot, bitter and pungent taste of $A$. melegueta seed (Doherty et al., 2010).

\section{Conclusion}

Ether extract of the spice generally had the highest inhibitory effect on the isolates, the microbial load and nutritional value of cheese

\section{References}

Adegoke G and AG Gopalakrishna (1998). Extraction and identification of antioxidants from the spice Afframomum Danielli. J. Am. Oil Chem. Soc. 75: 1047-1052

Afolabi MO, GO Adegoke and FM Mathooko (2011). Phytochemical Characterization of the Extracts of Aframomum danielli Flower, Leaf, Stem and Root. Afr. J. Agric. Res. 2011, 6(1):97 - 101.

Ahmed S and G Stoll (1996). Biopesticides. In: Biotechnology; Building on Farmers' Knowledge. Macmillan Education Ltd. 1996.

Amadioha AC and VI Obi (1999). Control of Anthranose diseases of Cowpea by Cymbopogon cunitus and Ocimum gratissimum. Acto Phytopath and Entom; 1999: 85 - 89.

AOAC (1995). Association of Official Analytica Chemist. Official Methods of Analysis, Arlington, VA. (1995)

Anon (1995). Curds and Whey. Spore; 1995:55, 14.

Ashaye OA, OO Taiwo and GO Adegoke (2006). Effect of Local Preservative (Aframomum danielli) on the Chemical and Sensory Properties of Stored warakanshi. Afr. J. Agric. Res: 2006. 1(1): 010-01

Aworh OC (2008). The Role of Traditional Food Processing Technologies in National Development: The West African Experience. In: Using Food Science and Technology to Improve Nutrition and Promote National Development, Chapter 3, (Robertson, G. L. \& Lupien, J. R. Eds.), Int. Union Food Sci. Tech. (IUFOST) 2008.

Aworh OC and M Egounlety (1985). Preservation of West African Soft Cheese by Chemical Treatment. J. Dairy Res; 1985. 52:189-195 made from it, with $3 \%$ of the extract being the most effective. It was also effective in significantly improving the percentage cheese yield, although it's sensory attributes were not good. From the results above, it is recommended that $3 \%$ ether extract of the spice $A$. melegueta should be added as a supplement in cheese preparation as it can significantly reduce the bacterial load of the cheese and also significantly improve the nutritional value of West African Soft Cheese made from it. Further work could be done to blend the $A$. melegueta fortification with other natural additives like honey as this might further improve the sensory and microbial status of the cheese.

Badmos AA and $K$ Joseph (2012). Effect of Fermented Maize Supernatant and Sodom Apple Coagulant on the Time, Temperature and Yield of Coagulation of West African Soft Cheese. J. Agric. Res. \& Dev.; 2012. 11(1): 327-332.

Bankole SA and YM Somorin (2010). Antifungal Activity of Extracts of Ocimum Gratissimum and Aframomum danielli against Moulds Isolated from Stored Rice. $10^{\text {th }}$ International Working Conference on Stored Product Protection. JuliusKühn-Archiv, 425; 2010.

Belewu MA, KY Belewu and CC Nkwunonwo (2005). Effect of Biological and Chemical Preservatives on the Shelf Life of West African Soft Cheese. Afr. J. Biotech; 2005. Vol 4 (10)

Chiejina NV and JA Ukeh (2012). Antimicrobial Properties and Phytochemical Analysis of Methanolic Extracts of Aframomum Melegueta And Zingiber Officinale on Fungal Diseases of Tomato Fruit. J. Natr Sc. Res.;2012. 2(6):1015.

Chen CM, DD Bogenrief, ME Johnson and B Gould (1996). Effect Of C:F Ratio On Stirred Curd Cheddar Cheese Yield. Dairy Pipeline. Wisconsin Center for Dairy Research. Spring 1996 Vol. 8 No. 2. University of Wisconsin-Extension College of Agricultural and Life Sciences. A Technical Resource for Dairy Manufacturers.

Dari L (2009). Effect of Different Solvent on the Extraction of Soya Bean Oil. M. Sc. Thesis. University of Science and Technology Kwame Nkrumah, Ghana; 2009.

Doherty VF, OO Olaniran and UC Kanife (2010). Antimicrobial Activities of Aframomum melegueta (alligator pepper). Int. J. Biol.; 2010. 2(2):126-131. 


\section{Aframomum melegueta on soft cheese}

Fawal Fawole MO, BA Osho (2007): Laboratory Manual of Microbiology. Spectrum Books Ltd: 2007.

Galal AM (1996). Antimicrobial Activity of 6-parado and Related Compounds. Int. J. Pharmacog; 1996. 31: 37-43.

Ilondu EM, BO Ejechi and JA Souzey (2001). Microbial Stability of Jam Prepared from Velvet Tamarind and Preserved by Combined Processes. Nig. J. of Micro; 2001. 5: 93-96.

Joseph JK and FA Akinyosoye (1997). Comparative Studies on Red Sorghum Extract and Other Chemicals as Preservatives for West African Soft Cheese. Int. Dairy J; 1997. 193-198.

Larmond E (1977). Laboratory methods for sensory evaluation of food. Publication no. 1637. Ottawa: Canada, Department of Agriculture. (1977).

O'Connor CB (1982). Traditional Cheese Making Manual. International Livestock Centre for Africa, Addis Ababa, Ethiopia. 1982.
Odebunmi EO, OO Oluwaniyi, GV Awolola and OO Adediji (2009) proximate and nutritional composition of kolanut (cola nitrida), bitter cola (garcinia kola) and alligator pepper (Aframomum melegueta). Polish African journal of Biotechnology 8(2): 308-310.

Ogundinwin JO (1978). A study of the traditional manufacturing processesand chemical composition of warankasi, a Nigerian soft white cheese. Nig. Food Journal2: 72-78

Oladipo IC and PD Jadesimi (2012). Microbiological Analysis and Nutritional Evaluation of West African soft cheese (wara) produced with different preservatives. American Journal of Food and Nutrition. 3(1): 13-21.

Oladunmoye MK and EO Dada (2007). Comparative studies on the Antimicrobial Activity of Leaf Extracts from Aframomum melegueta. Res. J. Botn.; 2007. 2(2): 95-107.

Okwu DE (2004). Phytochemicals and Vitamin Content of Indigenous Spices of South Eastern Nigeria. J. Sustain Agric. Envir. 2004. 6: 30-34.

Steel RGD and JH Torrie (1980). Principles and Procedures of Statistics, Second Edition, New York: McGraw-Hill; 1980 